\title{
Uji Homogenitas dan Stabilitas Suhu Mini Liquid Bath untuk Kalibrasi Termometer Digital Makanan
}

\author{
Liza Indrayani ${ }^{1}$, Margi Sasono ${ }^{2}$ \\ ${ }^{1}$ Program Studi Fisika Universitas Ahmad Dahlan \\ ${ }^{2}$ Pusat Studi Fisika Terapan (PUSFIT), Universitas Ahmad Dahlan \\ Universitas Ahmad Dahlan, Jalan Prof. Dr. Soepomo, S.H., Warungboto, Umbulharjo, Kota \\ Yogyakarta, Daerah Istimewa Yogyakarta \\ Email: lizaindrayani67@gmail.com
}

\begin{abstract}
Abstrak: Uji homogenitas dan stabilitas suhu di dalam Mini Liquid Bath untuk kalibrasi termometer digital dalam industri makanan atau Digital Food Thermometer telah dilakukan. Mini Liquid Bath yang akan diuji memiliki bentuk tabung silinder dengan diameter $6.5 \mathrm{~cm}$ dan tinggi $13.5 \mathrm{~cm}$. Uji homogenitas suhu dilakukan pada gradien radial dan axial pada silinder bath dengan menggunakan 6 buah sensor termokopel dari sebuah termometer multi channel. Sementara itu, uji stabilitas suhu menggunakan sebuah termometer yang diletakkan pada titik tengah geometris di dalam bath selama beberapa waktu. Selanjutnya, hasil uji ini digunakan untuk menentukan nilai sumbangan ketidakpastian dalam proses kalibrasi termometer digital dengan cara-cara ISO-GUM (International Standardization Organization-Guide Uncertainty Measurement). Berdasarkan hasil penelitian, kondisi stabil pada Mini Liquid Bath diperoleh yaitu pada titik suhu rendah berkisar $(8.38-9.09)^{\circ} \mathrm{C}$ dengan ketidakpastian $0.2^{\circ} \mathrm{C}$ dan suhu tinggi berkisar $(49.02-49.68)^{\circ} \mathrm{C}$ dengan ketidakpastian $0.19^{\circ} \mathrm{C}$ Hasil uji homogenitas, pada suhu rendah diperoleh ketidakpastian sebesar $0.97^{\circ} \mathrm{C}$ dan suhu tinggi diperoleh ketidakpastian $0.33^{\circ} \mathrm{C}$. Hasil kalibrasi termometer digital dengan menggunakan Mini Liquid Bath tersebut diperoleh koreksi $0.35^{\circ} \mathrm{C}$ untuk suhu rendah dengan ketidakpastian sebesar $2.00^{\circ} \mathrm{C}$. Sementara itu, untuk suhu tinggi diperoleh koreksi $-0.43^{\circ} \mathrm{C}$ dengan ketidakpastian sebesar $0.85^{\circ} \mathrm{C}$. Hasil kalibrasi ini dilaporkan dengan tingkat kepercayaan 95\% dan faktor cakupan $k=2$. Dari hasil tersebut, menunjukkan bahwa pada kalibrasi titik suhu rendah, ketidakpastian pengukuran sangat besar. Hal ini diduga akibat kontribusi signifikan ketidakpastian homogenitas dan stabilitas suhu pada titik suhu rendah.
\end{abstract}

Kata kunci: suhu, uji, homogenitas, stabilitas, Mini Liquid Bath, thermometer, kalibrasi

\section{PENDAhULUan}

Pengukuran suhu merupakan salah satu bagian terpenting dalam berbagai bidang kehidupan. Misalnya bidang kedokteran, seorang dokter menggunakan termometer klinis digital untuk mendiagnosa penyakit yang diderita oleh pasien. Termometer klinis memiliki rentang ukur antara $(35.5-42)^{\circ} \mathrm{C}(O I M L, 1995)$. Bidang lain yang memanfaatkan suhu ekstrim seperti bidang industri menggunakan jenis termokopel dan PT-100 digital dengan rentang suhu masing-masing $(-200-1700)^{\circ} \mathrm{C}$ dan $(-196-600)^{\circ} \mathrm{C}$ (WIKA, 2016). Oleh karena itu, harus ada penjaminan akurasi hasil pembacaan nominal suhu termometer digital mendekati suhu sebenarnya. Untuk itu kalibrasi termometer digital sangat penting dan krusial.

Proses pelaksanaan kalibrasi termometer digital memerlukan ruang atau wadah khusus (bath) dengan media tertentu sebagai alat bantu. Di dalam dunia kalibrasi disebut Enclosure. Media kalibrasi dapat berupa cairan, gas, atau padat tergantung pada jenis Enclosure dan kebutuhan rentang suhu dari termometer digital yang akan dikalibrasi. Misalnya, dalam industri pengujian kualitas makanan, Digital Food Thermometer merek TP101 memiliki 
ukuran mini dengan rentang suhu yang berkisar antara $(-50-300)^{\circ} \mathrm{C}$. Namun, kisaran suhu makanan yang baik dalam industri makanan yaitu diantara $(5-60)^{\circ} \mathrm{C}$ (Australia New Zealand Food Authority, 2001). Oleh karena itu, diperlukan Enclosureyang lebih efisien untuk kalibrasi termometer industri makanan.

Beberapa Enclosure yang ada di pasaran tidak dikhususkan untuk kalibrasi termometer makanan. Sebagian besar Enclosure komersial memiliki rentang ukur suhu yang tidak diperlukan dalam pengujian kualitas makanan. Beberapa diantaranya relatif mahal, tidak efektif dan efisien dalam proses kalibrasi. Oleh karena itu, solusi terbaik dalam kalibrasi termometer adalah menggunakan Enclosure yang sederhana dan sesuai dengan rentang ukur termometer yang sering digunakan dalam proses industri.

Salah satu Enclosure komersial yaitu Mini Temperature Calibration Bath atau Mini Liquid Bath komersial (ThermoWork, 2013). Enclosure ini memiliki harga yang relatif murah, portabel dan rentang suhu yang cukup terbatas antara $20^{\circ} \mathrm{C}$ di bawah suhu ruangan (kamar) sampai dengan $56^{\circ} \mathrm{C}$ menggunakan media air (ThermoWork, 2013). Namun, Mini Liquid Bath ini belum memberikan informasi tentang nilai homogenitas dan stabilitas suhunya. Homogenitas dan stabilitas suhu merupakan dua parameter dari beberapa parameter yang berkontribusi terhadap ketidakpastian dalam kalibrasi termometer (Drnovšek dkk, 1997).

Drnovšek dkk. (1997) telah melakukan penelitian terhadap suatu Enclosure (Cryostat) pada suhu $-55^{\circ} \mathrm{C}$ untuk membuat suatu prosedur umum untuk mengevaluasi ketidakpastian homogenitas dan stabilitas suhunya. Evaluasi nilai stabilitas suhu selama 20 menit dengan 1 termometer dan evaluasi nilai homogenitas pada gradien radial dan axial menggunakan 2 termometer dimana bath dalam keadaan stabil. Hasil ketidakpastian dari evaluasi pada bath ini diikutsertakan sebagai kontribusi ketidakpastian pada kalibrasi termometer dengan metode perbandingan.

Ince dkk. (2010) telah melakukan eksperimen untuk menentukan homogenitas dan stabilitas pada suatu Enclosure jenis Humidity Test Chamber. Uji homogenitas dan stabilitas suhu/kelembaban pada chamber dilakukan pada 9 titik. Setiap titik diuji menggunkan 3 termometer dan dilakukan 4 kali pengujian. Pengujian homogenitas dilakukan dalam keadaan suhu stabil. Berdasarkan hasil penelitian diperoleh ketidakpastian homogenitas sebesar 1,85\% rh untuk kelembaban dan $0,59^{\circ} \mathrm{C}$ untuk suhu pada chamber. Sementara itu nilai stabilitas diperoleh sebesar 0,192\% RH untuk kelembaban antara\% 20RH dan\% 80RH, dan 0,53 $3^{\circ} \mathrm{C}$ untuk suhu antara $15^{\circ} \mathrm{C}$ dan $40^{\circ} \mathrm{C}$.

Pornpatkul \& Suksathid (2013) membuat suatu sistem kontrol suhu pada liquid bath sebagai kalibrasi termometer digital. Karena pemberian sistem ini ketidakpastian homogenitas dan stabilitas suhu di dalam liquid bath menjadi lebih kecil sehingga mempengaruhi hasil ketidakpastian bentangan pada kalibrasi termometer digital. Berdasarkan hasil kalibrasi pada suhu $30^{\circ} \mathrm{C}, 40^{\circ} \mathrm{C}, 50^{\circ} \mathrm{C}, 60^{\circ} \mathrm{C}$ diperoleh ketidakpastian sebesar $0,15^{\circ} \mathrm{C}$.

Untuk itu dalam penelitian ini dilakukan uji homogenitas dan stabilitas suhu pada Enclosure jenis Mini Temperature Calibration Bath atau Mini Liquid Bath tersebut. Pengujian dilakukan berdasarkan metode yang pernah dilakukan oleh Drnovšek dkk, (1997). Namun, dalam penelitian ini digunakan sensor termometer digital yang berbeda yaitu termokopel tipe$\mathrm{K}$. Selain itu, pengujian ini mengacu pada pedoman evaluasi ketidakpastian ISO-Guide to the Expression of Uncertainty in Measurement (ISO-GUM). Diharapkan hasil uji ini dapat diperoleh nilai homogenitas dan stabilitas suhu dari Enclosure tersebut, sehingga dapat digunakan untuk menentukan kontribusi ketidakpastian pengukuran terutama dalam proses kalibrasi termometer digital. Dengan demikian, akan ada alternatif Enclosure yang sesuai dengan penggunaan rentang ukur termometer, dan akibatnya akurasi pembacaan termometer digital akan terjamin mutunya. 


\section{METODE PENELITIAN}

Pengujian ini dilakukan di Laboratorium Kalibrasi dan Uji (LKU) Universitas Ahmad Dahlan Yogyakarta. Beberapa komponen yang dibutuhkan dalam uji homogenitas dan stabilitas suhu pada Mini Liquid Bath yaitu media air murni $\mathrm{H}_{2} \mathrm{O}$ (aquadest) termometer termokopel tipe $\mathrm{K}$ dengan resolusi $0.01^{\circ} \mathrm{C}$, indikator suhu ditampilkan dalam multi-channel temperature meter merek Applent AT4710, Batang statip dilengkapi dengan indikator ketinggian termometer di dalam Termometer yang di kalibrasi dengan resolusi $0.1^{\circ} \mathrm{C}$ dan Termometer Standar (Reference Thermometer) dengan resolusi $0.01^{\circ} \mathrm{C}$. Mini Liquid Bath dan Reference Thermometer yang digunakan adalah alat uji yang dimiliki oleh Laboratorium Kalibrasi dan Uji (LKU) Universitas Ahmad Dahlan Yogyakarta.

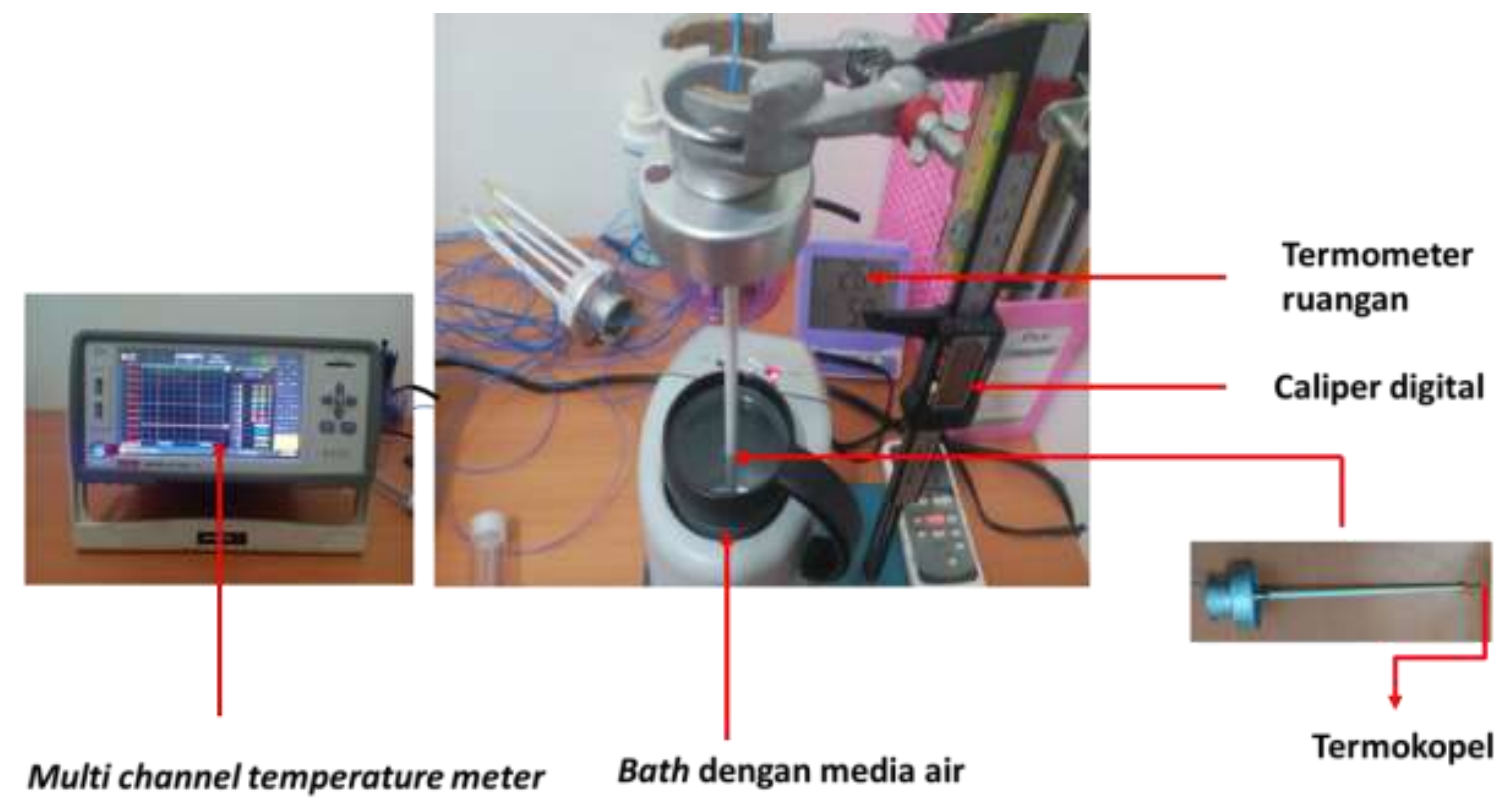

Gambar 1. Rancangan instrumen uji stabilitas suhu

Sebelum melakukan uji homogenitas suhu, terlebih dahulu dilakukan uji stabilitas suhu. Gambar 1 menunjukkan rancangan instrumen untuk uji stabilitas suhu. Pengujian ini menggunakan sebuah termometer yang diletakkan di titik tengah geometris bath. Indikator suhu termometer ditampilkan pada multi-channel temperature meter dalam sebuah grafik stabilitas suhu. Stabilitas suhu merupakan setengah dari selisih maksimum pada setiap sensor (TLAS, 2008). Sehingga dapa dirumuskan dalam persamaan berikut:

$$
T_{\text {stab. }}=\frac{\left|T_{\max }-T_{\min }\right|}{2}
$$

Di mana $T_{\text {stab. }}$ Adalah stabilitas suhu pada periode tertentu dan $T_{\max }, T_{\min }$ adalah suhu maksimum dan minimum yang ditunjukkan oleh termometer selama periode tersebut. stabilitas suhu merupakan sumber ketidakpastian baku tipe B dengan distribusi rectangular sehingga ketidakpastiannya merupakan $1 / \sqrt{3}$ dari nilai stabilitas suhunya. Sehingga dapat dirumuskan persamaan ketidakpastian berikut: 


$$
u\left(T_{\text {stab. }}\right)=\frac{T_{\text {stab. }}}{\sqrt{3}}
$$

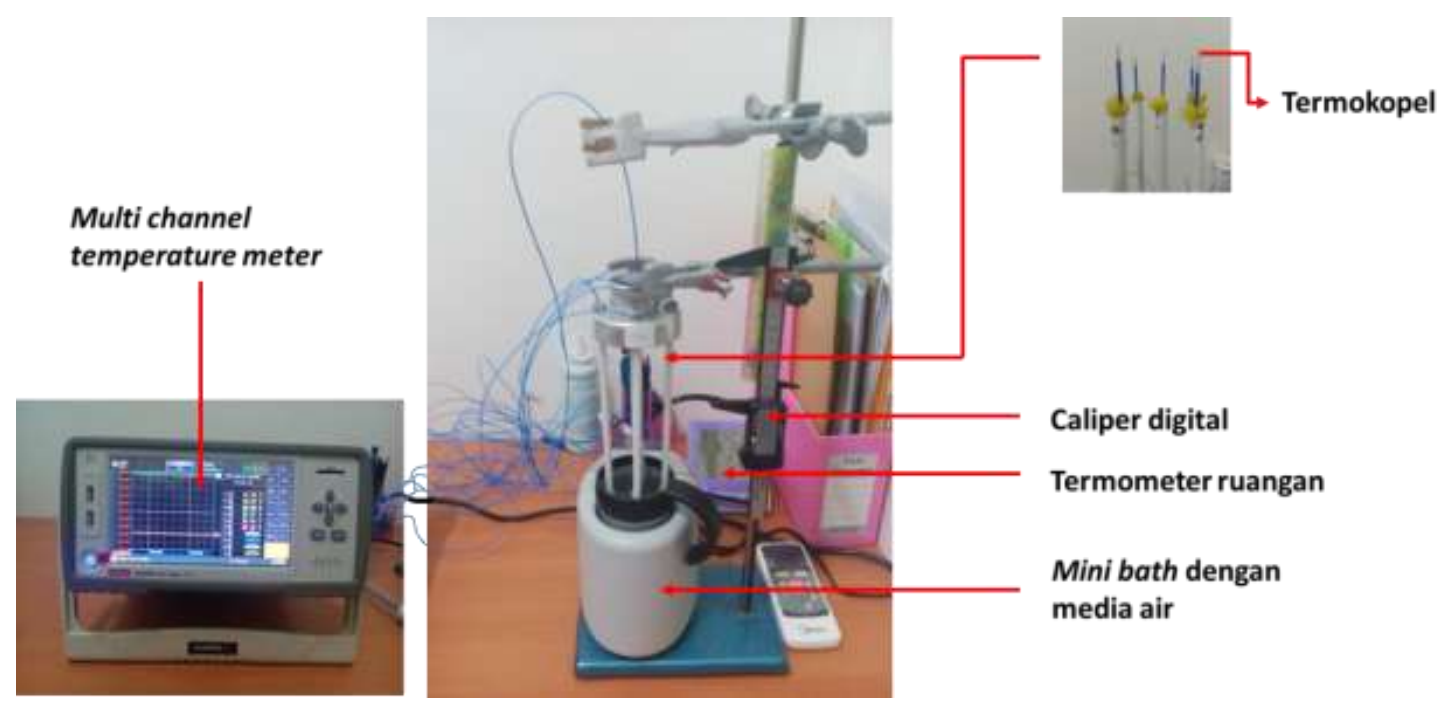

Gambar 2. Rancangan instrumen uji homogenitas suhu

Sementara itu, Gambar 2 menunjukkan rancangan instrumentasi uji homogenitas suhu. Pengujian ini menggunakan 6 termometer dimana 2 termometer sebagai referensi. Termometer tersebut menjadi referensi pengukuran secara radial dan referensi pengukuran secara axial. Berdasarkan Gambar 3, pengujian secara radial dilakukan dengan menurunkan termometer referensi radial $(\mathrm{CH}-1)$ secara bersamaan dan sejajar dengan 4 termometer lain (CH-3,CH-4, CH-5, CH-6) sejauh $1 \mathrm{~cm}$. Gambar 4 menunjukkan pengujian secara axial, termometer referensi axial (CH-2) berada tetap tidak bergerak di kedalaman maksimal bath ketika termometer lain diturunkan. Indikator suhu pada termometer ditampilkan dalam derajat Celcius $\left({ }^{\circ} \mathrm{C}\right)$ kemudian digambarkan dalam sebuah grafik perbandingan antara perpindahan termometer terhadap suhu. 


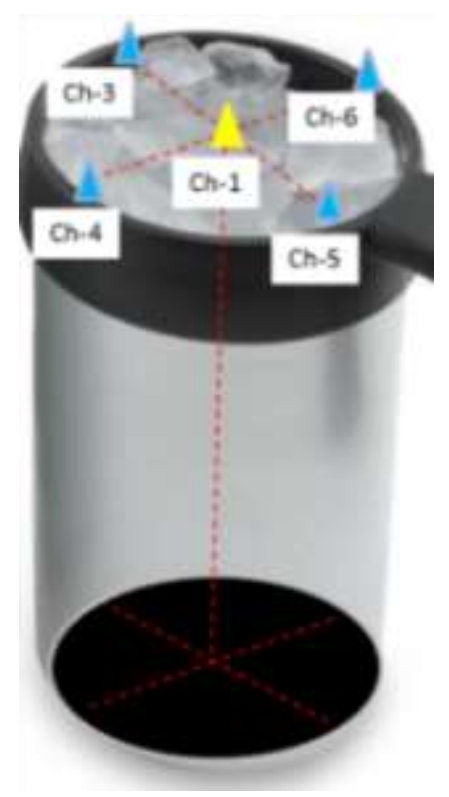

Gambar 3. Letak termometer pada uji homogenitas suhu radial

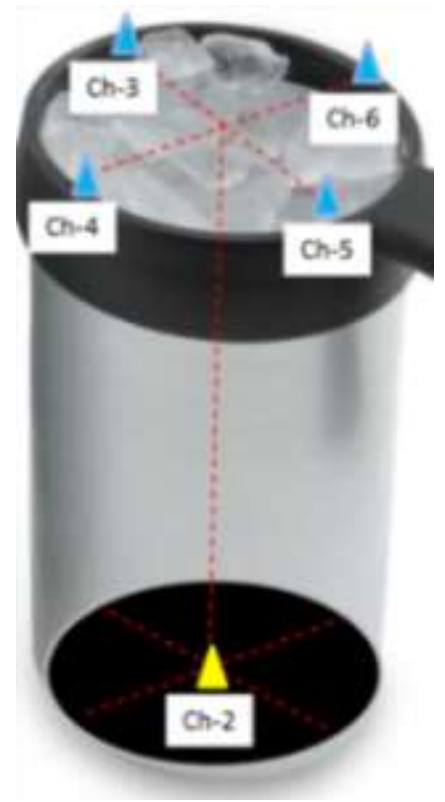

Gambar 4. Letak termometer pada uji homogenitas suhu axial

Di dalam dokumen Thai Laboratory Acreditation Scheme (2008) menyatakan bahwa homogenitas suhu merupakan selisih maksimum antara termometer pada titik referensi (titik tengah volume bath) dengan termometer lain pada keadaan stabil. Dalam hal ini, homogenitas suhu bath secara keseluruhan merupakan gabungan antara homogenitas suhu pada gradien radial dan axial yang dirumuskan dalam persamaan berikut:

$$
\left(T_{\text {hom. }}\right)=\sqrt{\left(T_{\text {axial }}\right)^{2}+\left(T_{\text {radial }}\right)^{2}}
$$

Di mana $T_{\text {bath }}$ adalah homogenitas suhu di dalam bath, $T_{\text {axial }}$ adalah homogenitas suhu pada gradien axial dan $T_{\text {radial }}$ adalah homogenitas suhu pada gradien radial. Homogenitas suhu 
pada gradien axial sama dengan gradien radial di mana homogenitas suhu dirumuskan dalam persamaan berikut:

$$
T_{\text {radial,axial }}=\max \left|T_{\text {ref }}-T_{i}\right|
$$

$T_{\text {ref }}$ adalah suhu yang ditunjukkan oleh termometer referensi dan $T_{i}$ adalah suhu yang ditunjukkan oleh termometer lain sebagai pembanding suhu termometer referensi.

Diketahui bahwa homogenitas suhu merupakan sumber ketidakpastian baku tipe B dengan distribusi rectangular sehingga ketidakpastiannya merupakan $1 / \sqrt{3}$ dari nilai homogenitas suhunya. Sehingga dapat dirumuskan persamaan ketidakpastian homogenitas suhu pada bath sebagai berikut:

$$
u\left(T_{\text {hom. }}\right)=\frac{T_{\text {hom }}}{\sqrt{3}}
$$

Di mana $u\left(T_{\text {hom }}\right)$ adalah ketidakpastian homogenitas suhu pada bath.

Nilai homogenitas dan stabilitas suhu Mini Liquid Bath diterapkan sebagai sumber ketidakpastian pada kalibrasi termometer digital seperti pada Gambar 5. Kalibrasi menggunakan metode perbandingan antara termometer referensi dan termometer yang dikalibrasi. Sumber-sumber ketidakpastian yang berasal dari termometer dan bath ini dievaluasi dengan metode ISO GUM.

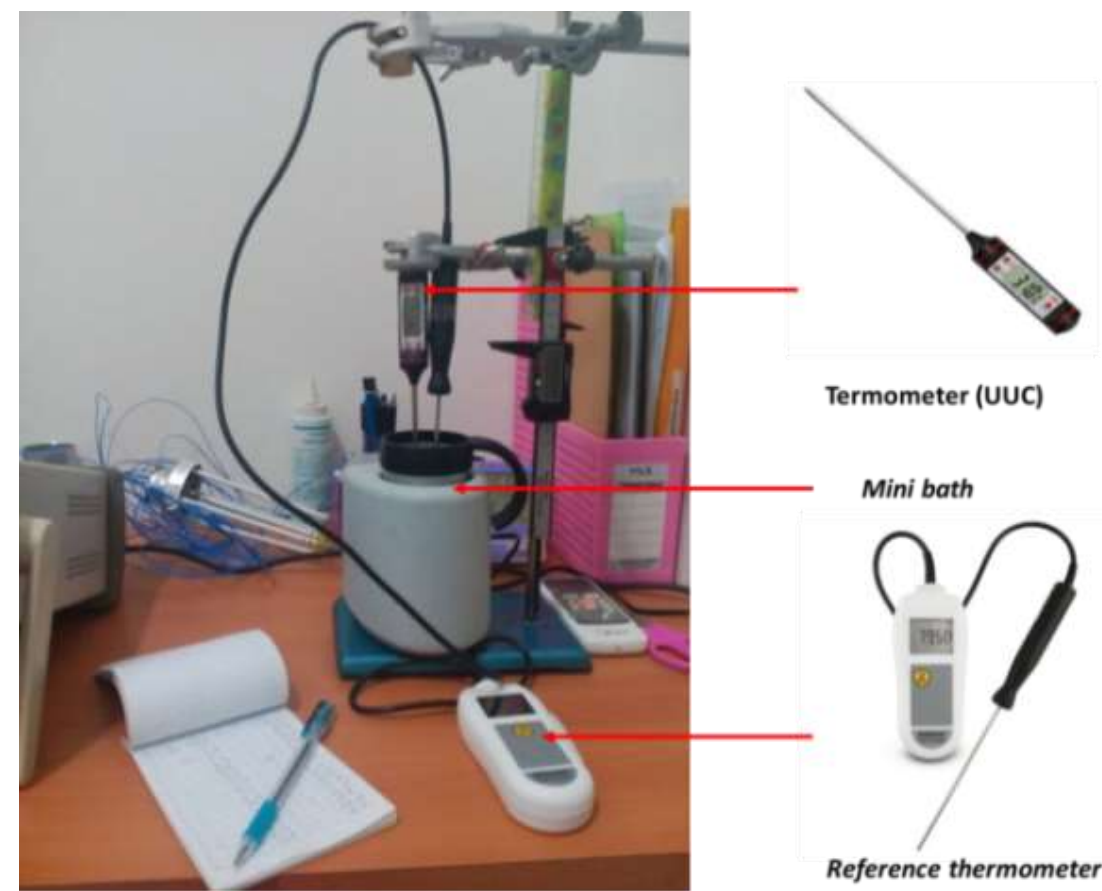

Gambar 5. Kalibrasi termometer digital

Metode pengukuran ketidakpastian yang digunakan secara luas dan diterima oleh badanbadan akreditasi. Secara umum, metode ISO GUM di dalam dokumen (KAN,2003) dilakukan melalui beberapa tahapan sebagai berikut:

1) Membuat model matematis bertujuan untuk menunjukkan hubungan antara besaran ukur (output, $Y$ ) dengan besaran lain yang mempengaruhinya (input, $X$ ) dirumuskan dalam persamaan:

$$
Y=f\left(X_{1}, X_{2}, \ldots, X_{N}\right)
$$


fmerupakan fungsi yang berisi setiap besaran yang dapat menyumbang komponen ketidakpastian terhadap hasil pengukuran besaran $Y$. Pengukuran suhu pada termometer membentuk model matematis yang dirumuskan dalam persamaan:

$$
Y=\text { penunjukkan alat }+ \text { koreksi }
$$

Penunjukkan alat dan koreksi memiliki ketidakpastian yang berasal dari resolusi dan sertifikat kalibrasi.

2) Mengidentifikasisumber ketidakpastian contohnya pada pengukuran suhu termometer pada Gambar 1, pengukuran tersebut dapat dipengaruhi oleh kondisi lingkungan, media, sertifikat kalibrasi dan lain sebagainya.

3) Mengevaluasi sumber ketidakpastian bakuke dalam tipe A dan tipe B. Evaluasi ketidakpastian Tipe A dengan metode statistik.

Ketidakpastian baku tipe A:

derajat kebebasan tipe A:

$$
u\left(x_{i}\right)=s\left(x_{i}\right) / \sqrt{n}
$$

$$
v_{i}=n-1
$$

Di mana $u\left(x_{i}\right)$ adalah ketidakpastian baku dari setiap sumber ketidakpastian, $s\left(x_{i}\right)$ adalah standar deviasi, $v_{i}$ adalah derajat kebebasan dan $n$ adalah banyak data. Sementara itu, evaluasi ketidakpastian tipe $\mathrm{B}$ diperoleh dari data pengukuran sebelumnya, pengalaman, sifat-sifat material/instrument secara umum, data dari laporan/sertifikasi kalibrasi, data yang diambil dari buku/literatur (cecep dkk, 2011). Disamping itu, ketidakpastian juga diberikan oleh distribusi probabilitas dalam batas tertentu $\pm a$ (KAN, 2003).

4) Melakukan evaluasi koefisien sensitifitas berdasarkan turunan parsial dari fungsi yang mewakili model matematis pengukuran dirumuskan dalam persamaan:

$$
c_{i}=\partial y / \partial x_{i}
$$

Dimana $y$ adalah besaran terukur dan $x_{i}$ adalah besaran yang mempengaruhi pengukuran besaran $y$.

5) Menghitung ketidakpastian baku gabungan $u_{c}(\mathrm{y})$ menggunakan persamaan:

$$
u_{c}(\mathrm{y})=\sqrt{\sum_{i=1}^{n}\left\{c_{i} u\left(x_{i}\right)\right\}^{2}}
$$

6) Menghitung derajat kebebasan effektif $v_{e f f}$ menggunakan persamaan:

$$
v_{e f f}=\frac{\left\{u_{c}(y)\right\}^{4}}{\sum_{1}^{N} \frac{\left\{c_{i} u\left(x_{i}\right)\right\}^{4}}{v_{i}}}
$$

7) Menghitung ketidakpastian bentangan $U$ menggunakan persamaan:

$$
U=k \times u_{c}(y)
$$

Nilai $k$ diperoleh dari tabel t-student distribution berdasarkan nilai derajat kebebasan effektif(KAN, 2003). Nilai ketidakpastian bentangan tersebut menjadi ketidakpastian terhadap hasil pengukuran besaran ukur $Y$.

\section{HASIL DAN PEMBAHASAN}

Telah dilakukan eksperimen untuk menentukan stabilitas dan homogenitas suhu Mini Liquid Bath dalam keadaan stabil. Keadaan suhu stabil pada suhu rendah pada Gambar 6 dengan rentang suhu $(8.38-9.09){ }^{\circ} \mathrm{C}$ dan suhu tinggi pada Gambar 7 dengan rentang 
suhu $(49.02-49.68)^{\circ} \mathrm{C}$. Hasil uji stabilitas suhu dan ketidakpastiannya ditunjukkan pada Tabel 1.

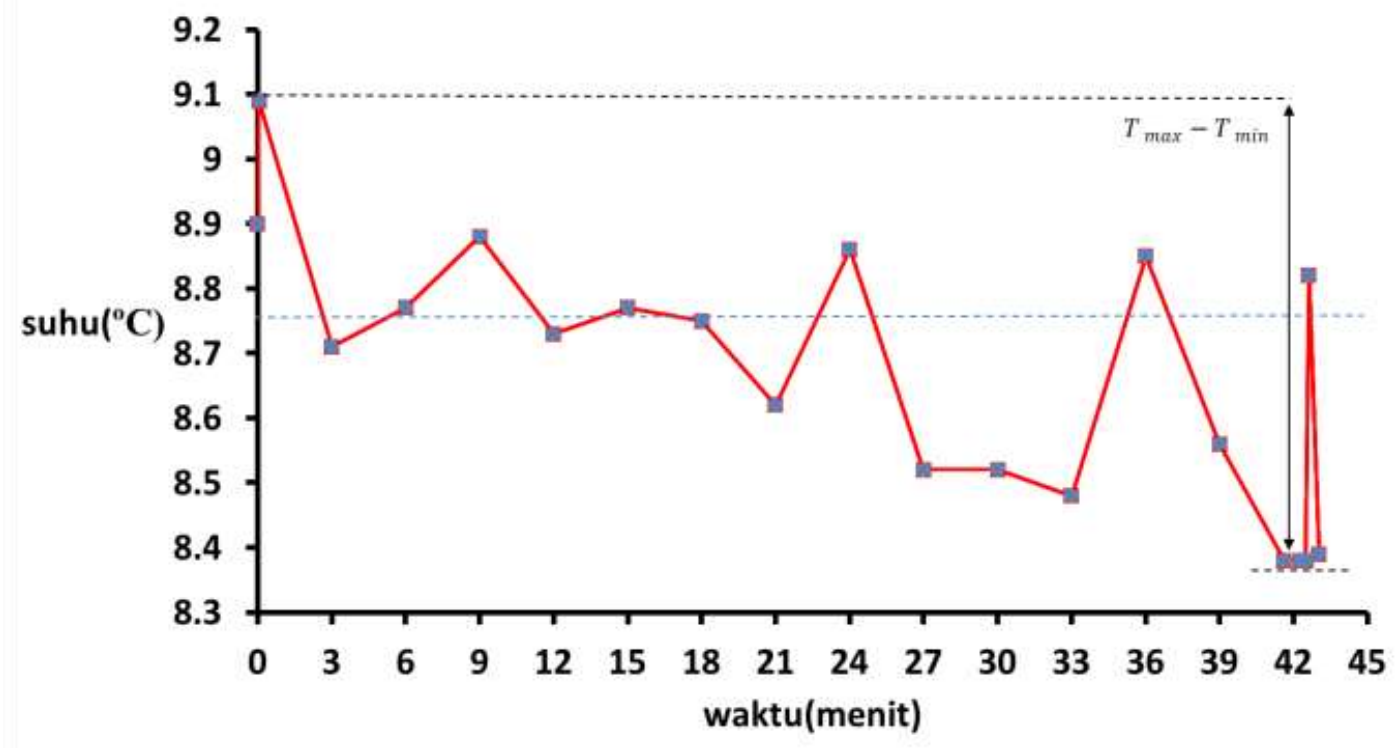

Gambar 6.Grafik stabilitas suhu rendah

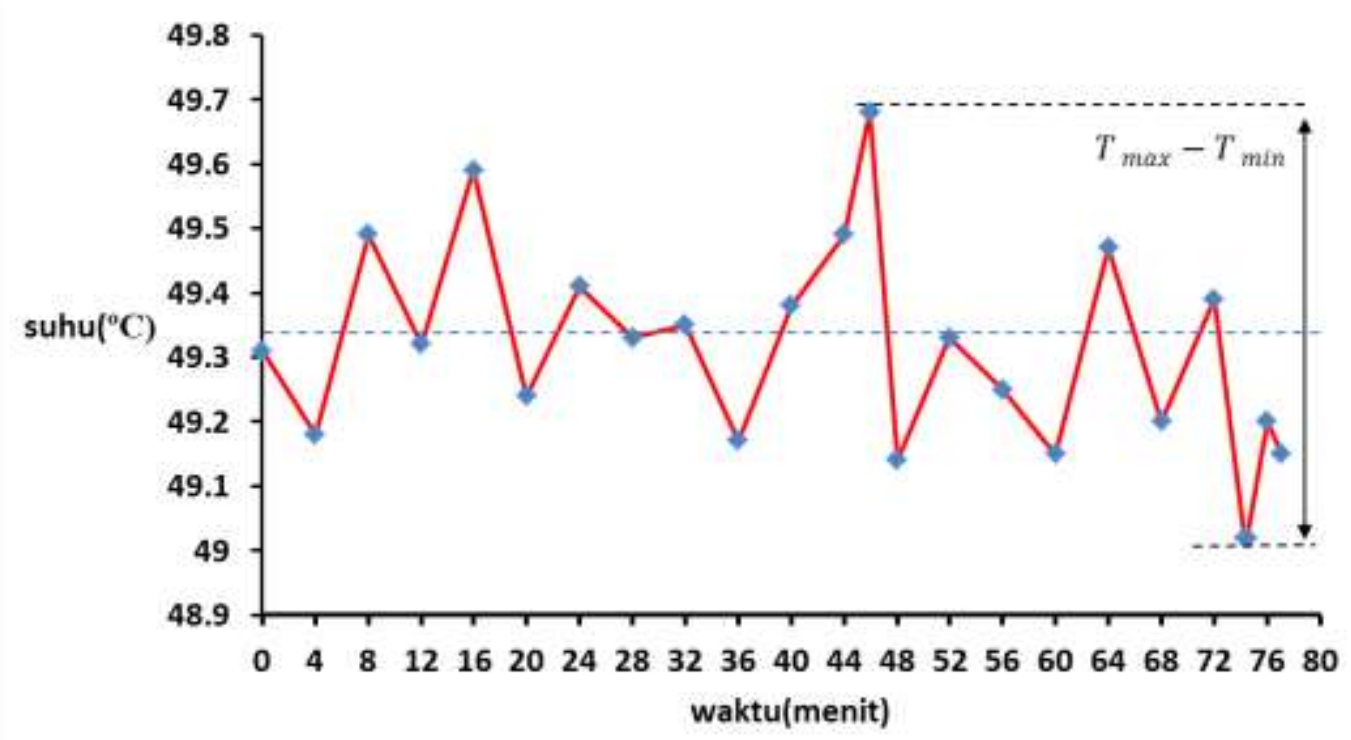

Gambar 7.Grafik stabilitas suhu tinggi

Uji homogenitas suhu dilakukan dalam keadaan suhu stabil. Berdasarkan posisi termometer, pengujian secara radial pada Gambar 3 dan axial pada Gambar 4 diperoleh grafik homogenitas suhu gradien radial dan axial. Gambar 8 dan 9 menunjukkan grafik homogenitas suhu rendah dalam rentang suhu stabil $(8.38-9.09)^{\circ} \mathrm{C}$. Gambar 10 dan 11 menunjukkan grafik homogenitas pada suhu tinggi dalam rentang suhu stabil $(49.02-49.68)^{\circ} \mathrm{C}$. 


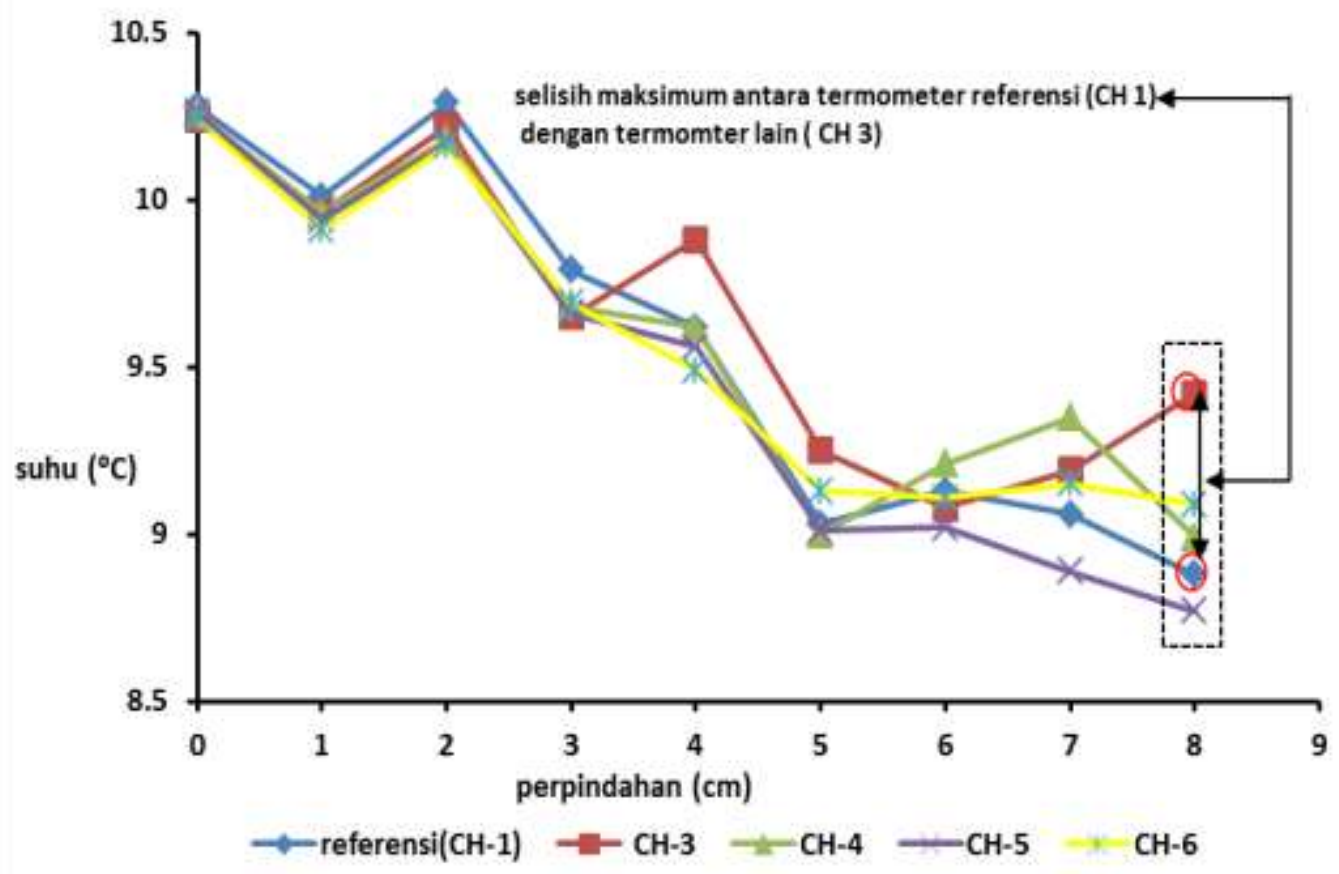

Gambar 8. Grafik homogenitas suhu gradien radial pada suhu rendah

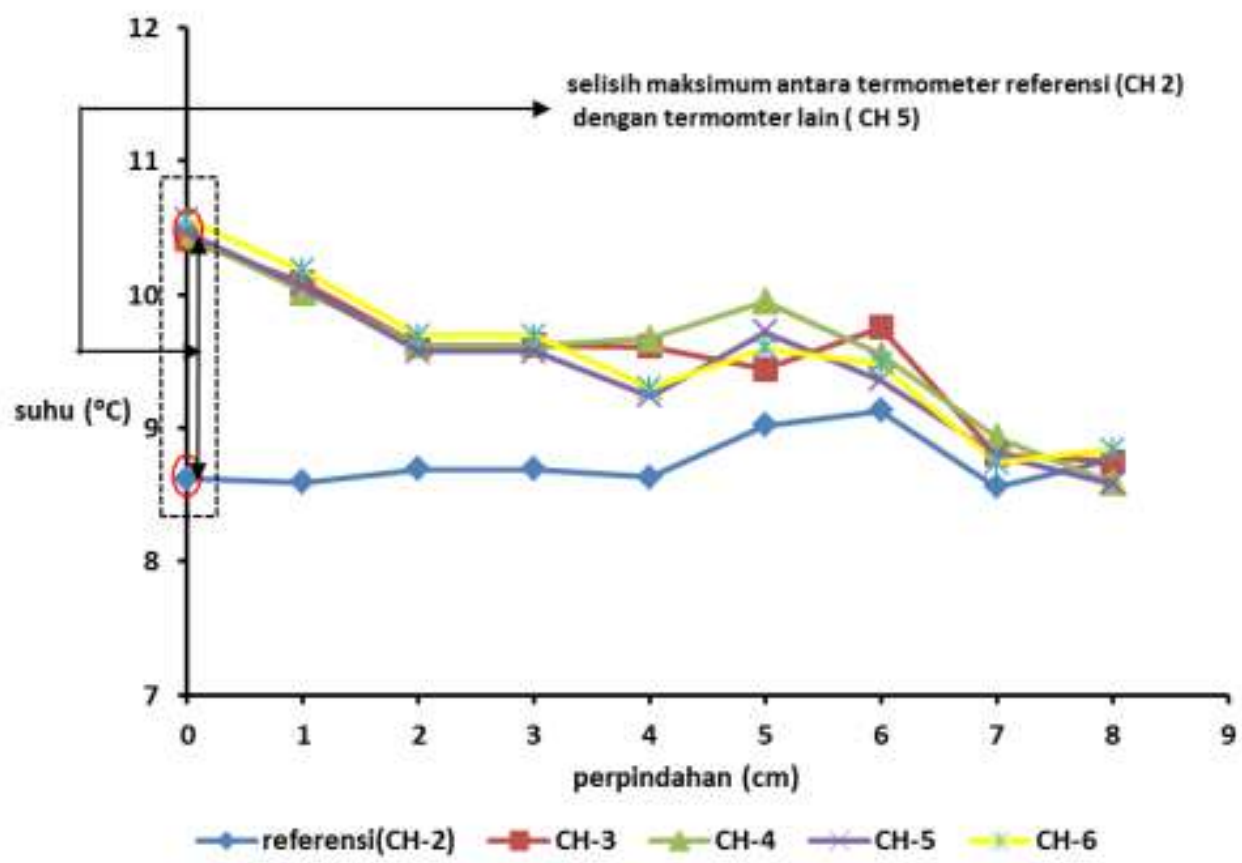

Gambar 9. Grafik homogenitas suhu gradien axial pada suhu rendah

Grafik homogenitas suhu secara radial dan axial merupakan hubungan antara suhu $\left({ }^{\circ} \mathrm{C}\right)$ dan perpindahan termometer $(\mathrm{cm})$ di sepanjang kedalaman bath. Gambar 8 menunjukkan homogenitas suhu pada gradien radial diperoleh sebesar $0.54^{\circ} \mathrm{C}$ dengan ketidakpastian $0.31^{\circ} \mathrm{C}$ pada kedalaman $8 \mathrm{~cm}$. Gambar 9 menunjukkan homogenitas suhu rendah pada gradien axial 
sebesar $1.59^{\circ} \mathrm{C}$ dengan ketidakpastian $0.92^{\circ} \mathrm{C}$ pada kedalaman $0 \mathrm{~cm}$ (permukaan bath dengan syarat termometer tercelup dalam aquadest).

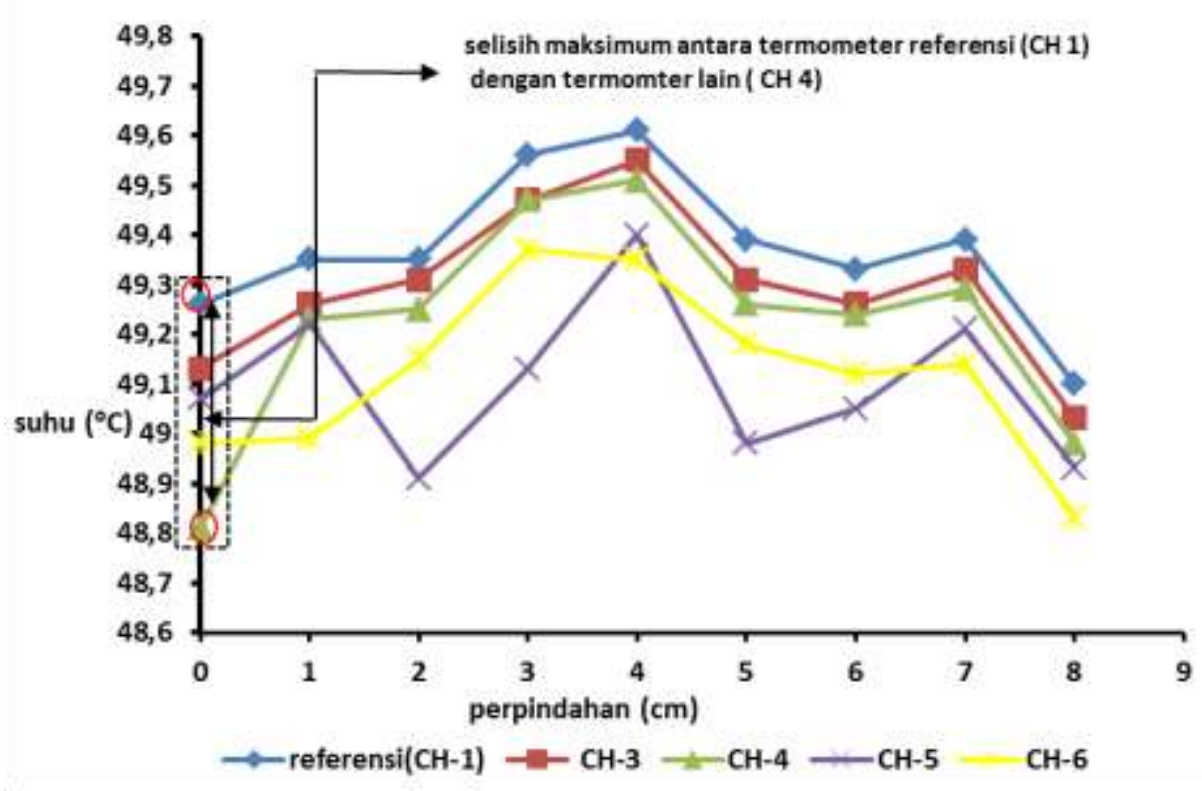

Gambar 10. Grafik homogenitas suhu gradien radial pada suhu tinggi

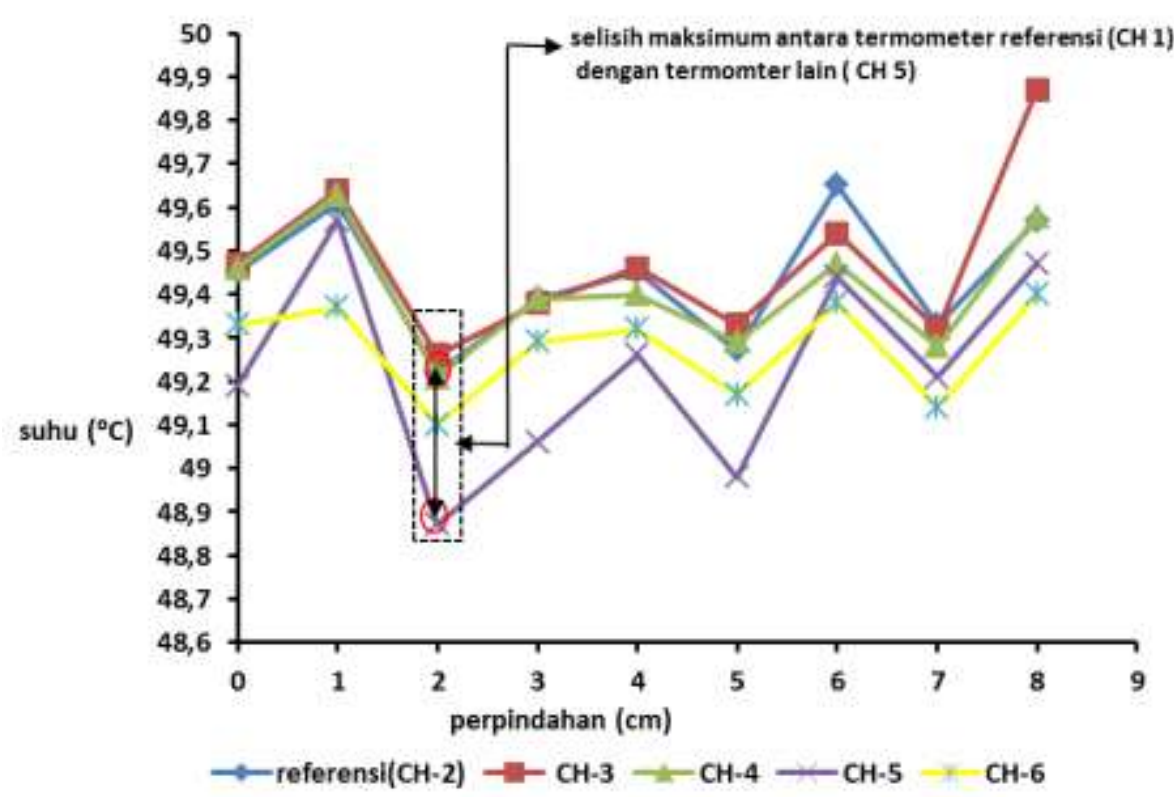

Gambar 11. Grafik homogenitas suhu gradien axiall pada suhu tinggi

Berdasarkan Gambar 10, nilai homogenitas suhu pada gradien radial diperoleh sebesar $0.45^{\circ} \mathrm{C}$ dengan ketidkpastian $0.26^{\circ} \mathrm{C}$ pada kedalaman $0 \mathrm{~cm}$. Sementara itu, Gambar 11 menunjukkan homogenitas gradien axial sebesar $0.35^{\circ} \mathrm{C}$ dengan ketidakpastian $0.20^{\circ} \mathrm{C}$ pada kedalaman 2 $\mathrm{cm}$. Gabungan antara nilai homogenitas suhu pada gradien radial dan axial merupakan nilai homogenitas suhu pada bath secara keseluruhan. Nilai homogenitas suhu dan ketidakpastian bath tersebut ditunjukkan pada Tabel 1. 
Nilai ketidakpastian stabilitas dan homogenitas suhu bath menjadi salah satu sumber ketidakpastian pada kalibrasi termometer digital di titik tersebut. Gambar 12 menunjukkan kalibrasi pada suhu rendah diperoleh persentase ketidakpastian homogenitas suhu paling tinggi sebesar $89.81 \%$. Sedangkan pada kalibrasi suhu tinggi, ketidakpastian homogenitas suhu $47.42 \%$ ditunjukkan pada Gambar 13.

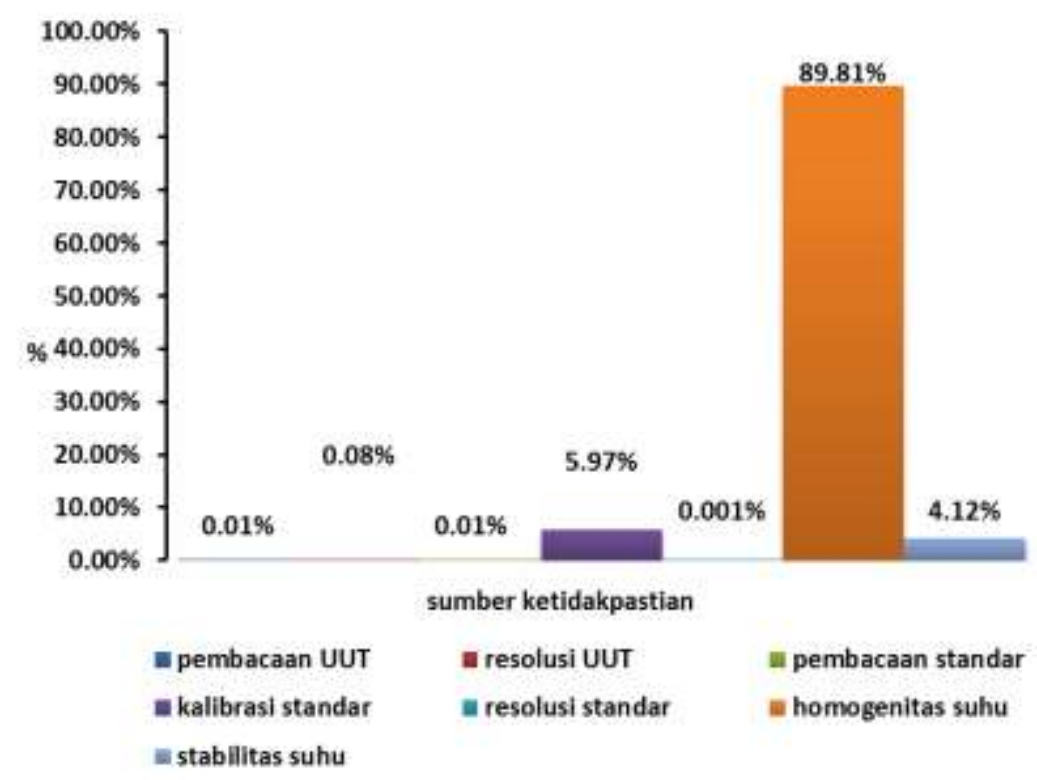

Gambar 12. Persentase sumber-sumber ketidakpastian kalibrasi termometer pada suhu rendah

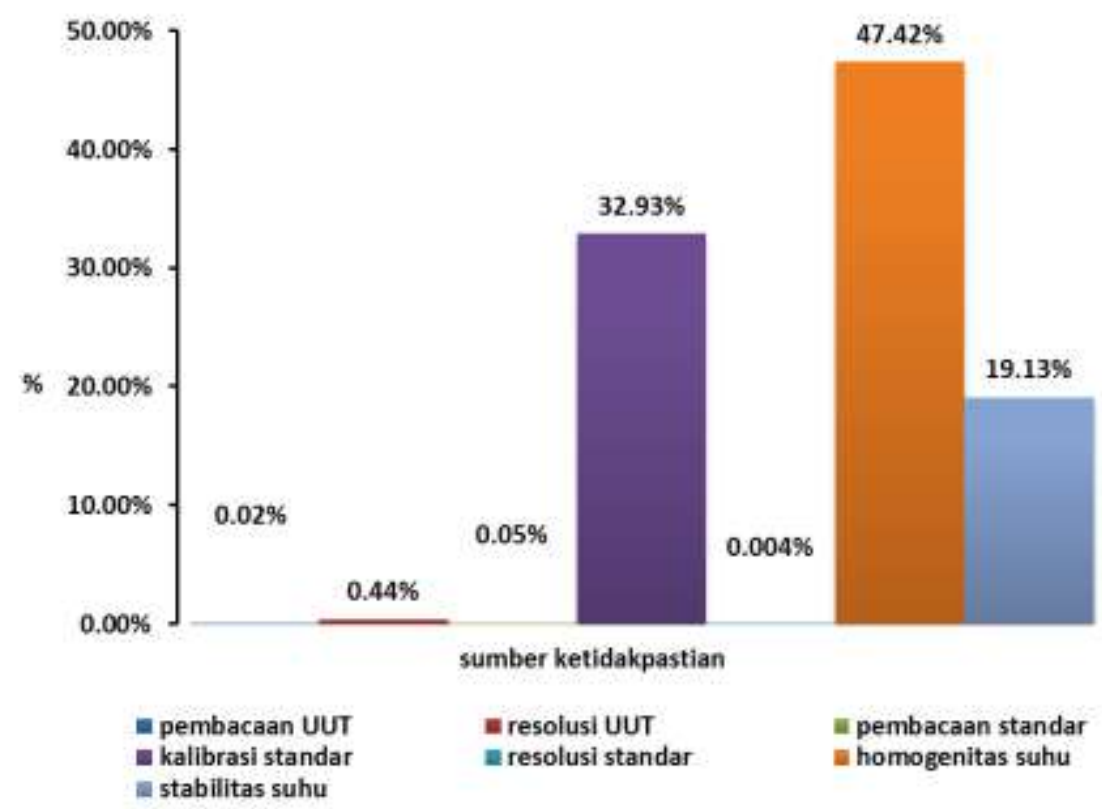

Gambar 13. Persentase sumber-sumber ketidakpastian kalibrasi termometer pada suhu tinggi

Kalibrasi termometer digital menghasilkan koreksi dan ketidakpastian terhadap instrumen yang dikalibrasi (Unit Under Calibration). Koreksi dan ketidakpastian tersebut ditunjukkan pada Tabel 2. Tingkat kepercayaan terhadap kalibrasi yaitu 95\% dengan faktor cakupan $k=$ 2 . 
Tabel 1. Hasil uji stabilitas dan homogenitas suhu Mini Liquid Bath

\begin{tabular}{cccccc}
\hline \multirow{2}{*}{ No } & \multirow{2}{*}{ Suhu } & \multicolumn{2}{c}{ Homogenitas suhu } & \multicolumn{2}{c}{ Stabilitas suhu } \\
& $\rho C$ Homogenitas & Ketidakpastian & Stabilitas & Ketidakpastian \\
& $\left({ }^{\circ}\right.$ ) & $\left({ }^{\circ} \mathrm{C}\right)$ & $\left.{ }^{\circ} \mathrm{C}\right)$ & $\left.{ }^{\circ} \mathrm{C}\right)$ & $\left({ }^{\circ} \mathrm{C}\right)$ \\
\hline 1 & $8.38-9.09$ & 1.68 & 0.97 & 0.36 & 0.20 \\
2 & $49.02-49.68$ & 0.57 & 0.33 & 0.33 & 0.19 \\
\hline
\end{tabular}

Tabel 2. Hasil kalibrasi termometer digital

\begin{tabular}{cccccc}
\hline \multirow{2}{*}{ No } & \multirow{2}{*}{ Suhu } & \multicolumn{2}{c}{ Rata-rata } & \multirow{2}{*}{ Ketidakpastian } & \multirow{2}{*}{ Koreksi } \\
& $(\rho C)$ & $\rho C)$ & $\rho C)$ & $\rho C)$ & $\rho C)$ \\
\hline 1 & $8.38-9.09$ & 8.59 & 8.23 & 0.35 & 2.00 \\
2 & $49.02-49.68$ & 49.83 & 49.86 & -0.43 & 0.85 \\
\hline
\end{tabular}

\section{KESIMPULAN}

Uji homogenitas suhu dilakukan pada gradien radial dan axial di dalam bath. Pengujian menggunakan 6 termometer di mana dua diantaranya sebagai referensi radial dan referensi axial. Termometer digerakkan dari permukaan bath $(0 \mathrm{~cm})$ hingga ke dasar bath $(8 \mathrm{~cm})$. Ketidakpastian dari homogenitas dan stabilitas suhu menjadi sumber ketidakpastian pada kalibrasi termometer digital. Berdasarkan analisa diperoleh ketidakpastian homogenitas suhu pada rentang $(8.38-9.09)^{\circ} \mathrm{C}$ sebesar $0.97^{\circ} \mathrm{C}$. Sementara itu, pada rentang suhu $(49.02-$ $49.68)^{\circ} \mathrm{C}$ diperoleh ketidakpastian homogenitas suhu sebesar $0.33^{\circ} \mathrm{C}$.

Kalibrasi pada suhu rata-rata $8.23^{\circ} \mathrm{C}$ dengan ketidakpastian homogenitas suhu sebesar $0.97^{\circ} \mathrm{C}$ diperoleh ketidakpastian kalibrasi termometer digital sebesar $2.00^{\circ} \mathrm{C}$. Sementara itu, pada suhu rata-rata $49.86^{\circ} \mathrm{C}$ dengan ketidakpastian homogenitas suhu sebesar $0.33^{\circ} \mathrm{C}$ diperoleh ketidakpastian kalibrasi termometer digital sebesar $0.85{ }^{\circ} \mathrm{C}$. Berdasarkan hasil ketidakpastian dan persentase sumber-sumber ketidakpastian, dapat disimpulkan bahwa besar atau kecilnya ketidakpastian dari homogenitas suhu sangat mempengaruhi hasil ketidakpastian dalam suatu kalibrasi termometer digital.

\section{SARAN}

Mini Liquid Bath tidak memiliki kontrol suhu/setting point sehingga tidak dapat dilakukan uji homogenitas suhu pada titik kerja yang lain. Meskipun pengujian dalam keadaan stabil pada suhu tertentu (panas/dingin), suhu pada bath masih dipengaruhi oleh lingkungan, termometer, dan instrumen lain yang dapat mempengaruhi hasil pembacaan pada termometer. Hal tersebut mengakibatkan tingginya nilai ketidakpastian

Dapat dilakukan uji homogenitas dan stabilitas suhu menggunakan metode lain seperti metode yang dilakukan oleh İnce dkk, 2010. Pengujian homogenitas dan stabilitas suhu dilakukan secara bersamaan selama waktu tertentu menggunakan 9 termometer. Hasil uji tersebut dapat menjadi pembanding metode radial dan axial yang telah dilakukan.

\section{DAFTAR PUSTAKA}

ANZFA (Australia New Zealand Food Authority). 2001. Standar-standar keselamatan makanan dan syarat-syarat pengawasan suhu. Canberra: Commonwealth Department of Health and Aged Care.

Sulaeman, C., Kusnadi. 2011. Kalibrasi Temperatur pada PT100 dan Thermocouple. 
JURNAL ILMIAH ELITE ELEKTRO, VOL. 2, NO. 2, SEPTEMBER 2011: 99-104.

Drnovšek, J., Bojkovski, J., Pušnik, I.1997. A general procedure for evaluation of calibration baths in precision temperature measurements.Canada: IEEE Instrumentation and Measurement Technology Conference

İnce, A.T., Aslanbay,G., Davut, A. 2010. Determination of homogeneity and stability of humidity test chambers. Turki: Turkish Standards Institution

KAN (Komite Akreditasi Nasional). 2003. Pedoman evaluasi dan pelaporan ketidakpastian pengukuran.Jakarta: National Accreditation Body of Indonesia.

Pornpatkul, C., \& Suksathid, W. 2013. Liquid bath digital control system For digital thermometer calibration. Thailand: Department of Instrumentation and Control Engineering, Pathumwan Institute of Technology

ThermoWorks. 2013. Operation instructure mini temperature calibration bath. Amerika: ThermoWorks.

TLAS (Thai Laboratory Acreditation Scheme). 2008. Guidelines for calibration and checks of temperature controlled Enclosures. Thailand: TLAS.

WIKA. 2016. Operating limits and tolerances of platinum resistance thermometers per EN 60751: 2008. Germany: Alexander Wiegend. 